\title{
A NEW SPECIES OF ANATHALLIS (ORCHIDACEAE: PLEUROTHALLIDINAE) FROM BRAZIL
}

\author{
A. L. V. Toscano de Brito ${ }^{1,2}$ \\ ${ }^{1}$ Marie Selby Botanical Gardens, 811 South Palm Avenue, Sarasota, FL 34236-7726, U.S.A. \\ E-mail: atoscano@selby.org \\ ${ }^{2}$ Orchid Herbarium of Oakes Ames, Harvard University Herbaria, 22 Divinity Avenue, Cambridge, \\ Massachusetts 20138, U.S.A.
}

\begin{abstract}
Anathallis luteola is newly described and illustrated from the state of Bahia, northeast Brazil. It is similar to A. guarujaensis from which it can be distinguished by the smaller flowers, the successive twoflowered raceme, and shape of its floral segments. A note on the latter species is also provided.
\end{abstract}

Key words: Bahia, Brazilian Atlantic forest, taxonomy

Introduction. The genus Anathallis Barb.Rodr. (Orchidaceae) comprises about 116 species (Karremans 2016) of epiphytic orchids, mostly South American in distribution. According to Brazilian Flora 2020 (in construction), 92 species of Anathallis are found in Brazil, of which 76 are endemic. However, these figures include a number of species recently transferred to Stelis Sw. (Chiron, Guiard \& van den Berg 2012, Karremans 2014) and to Lankesteriana Karremans (Karremans 2014, 2015). Following this narrower concept and including the new species described herein, some recent additions not yet listed in Brazilian Flora 2020 (Chiron, Guiard \& Bolsanello 2013, Krahl et al. 2016) and excluding a number of obscure names and synonyms, the current accepted Anathallis names for the Brazilian flora is approximately 72 species.

During recent fieldwork and visits to private and public collections in Brazil, aiming towards a taxonomic revision of the Brazilian Anathallis, an undescribed species has been discovered. It is herein described and illustrated.

\section{Anathallis luteola Toscano, sp. nov.}

TYPE: Brazil. Bahia: Without precise locality, obtained from a collector, cultivated by Maria Rita Cabral at her property in Paty do Alferes, state of Rio de Janeiro, fl. cult. 16 March 2015, A. Toscano de Brito 3352 (holotype: UPCB). Fig. 1-2.
DiAGNOSIS. This small, caespitose species is characterized by very short ramicauls, thickly coriaceous leaves, and two orange-yellow or greenish-yellow successive flowers; oblong-elliptical, obtuse petals; and the oblongtrilobed lip with minute lateral lobes. It is similar to A. guarujaensis (Hoehne) F. Barros from which it is distinguished by the smaller flowers, the successive 2-flowered raceme, 3-veined sepals, obtuse petals, and glabrous lateral lobules of the lip.

Plant to $c a .3 \mathrm{~cm}$ tall, epiphytic, caespitose. Roots thick. Ramicaul 2-5 $\mathrm{mm}$ long, erect, stout, short, enclosed by 2 evanescent sheaths. Leaf $10-25 \times 5-7$ $\mathrm{mm}$, erect, thickly coriaceous, spathulate-elliptical, the base cuneate into a petiolate base, the apex obtuse to subacute, minutely tridenticulate. Inflorescence 1 to several successive racemes that emerge from an annulus below the abscission layer, shorter than the leaf, erect to suberect; peduncle 5-10 $\mathrm{mm}$ long; rachis inconspicuous. Floral bract $1.0-1.5 \mathrm{~mm}$ long, thin. Flowers 2, opening in succession, only one flower open at a time; pedicel 1.5-2.0 mm long; ovary $0.8-$ $1.0 \mathrm{~mm}$ long; sepals translucent greenish-yellow or orange-yellow, glabrous, 3-veined, acute, the dorsal sepal 3.0-3.5 × 1.25-1.50 mm, oblong-lanceolate to slightly ovate-lanceolate, slightly concave and curved over the column, free from the lateral sepals, 3-veined, the lateral sepals $3.0-3.3 \times 1.0-1.2$, slightly oblique, oblong-lanceolate, shortly connate at base, forming a 

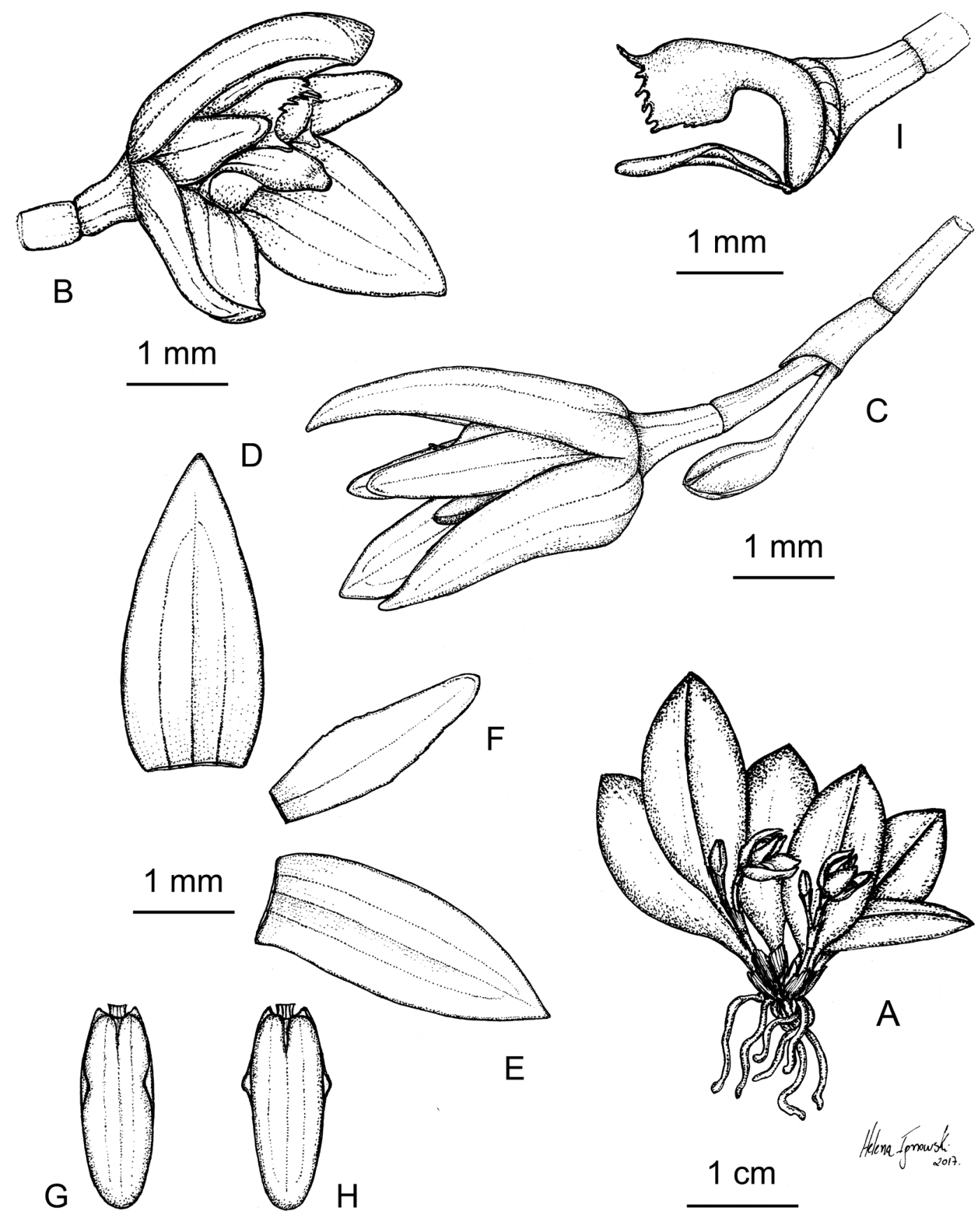

Figure 1. Anathallis luteola. A. Habit. B. Flower, $3 / 4$ view. C. Apical portion of inflorescence, showing bud and flower in side

view. D. Dorsal sepal. E. Lateral sepal. F. Petal. G. Lip, from above. H. Lip, expanded. I. Ovary, column and lip, side view. Drawn by Helena Ignowski based on the holotype (A. Toscano de Brito 3352, UPCB).

shallow mentum with the column-foot; petals same color as sepals, $2.3-2.6 \times 0.60-0.75 \mathrm{~mm}$, oblongelliptical, slightly convex and thickened at the apical third, 3-veined, margins entire or microscopically erose, the apex obtuse; lip same color as sepals and petals, $1.75-2.00 \times 0.75-0.80 \mathrm{~mm}$, oblong-trilobed, 


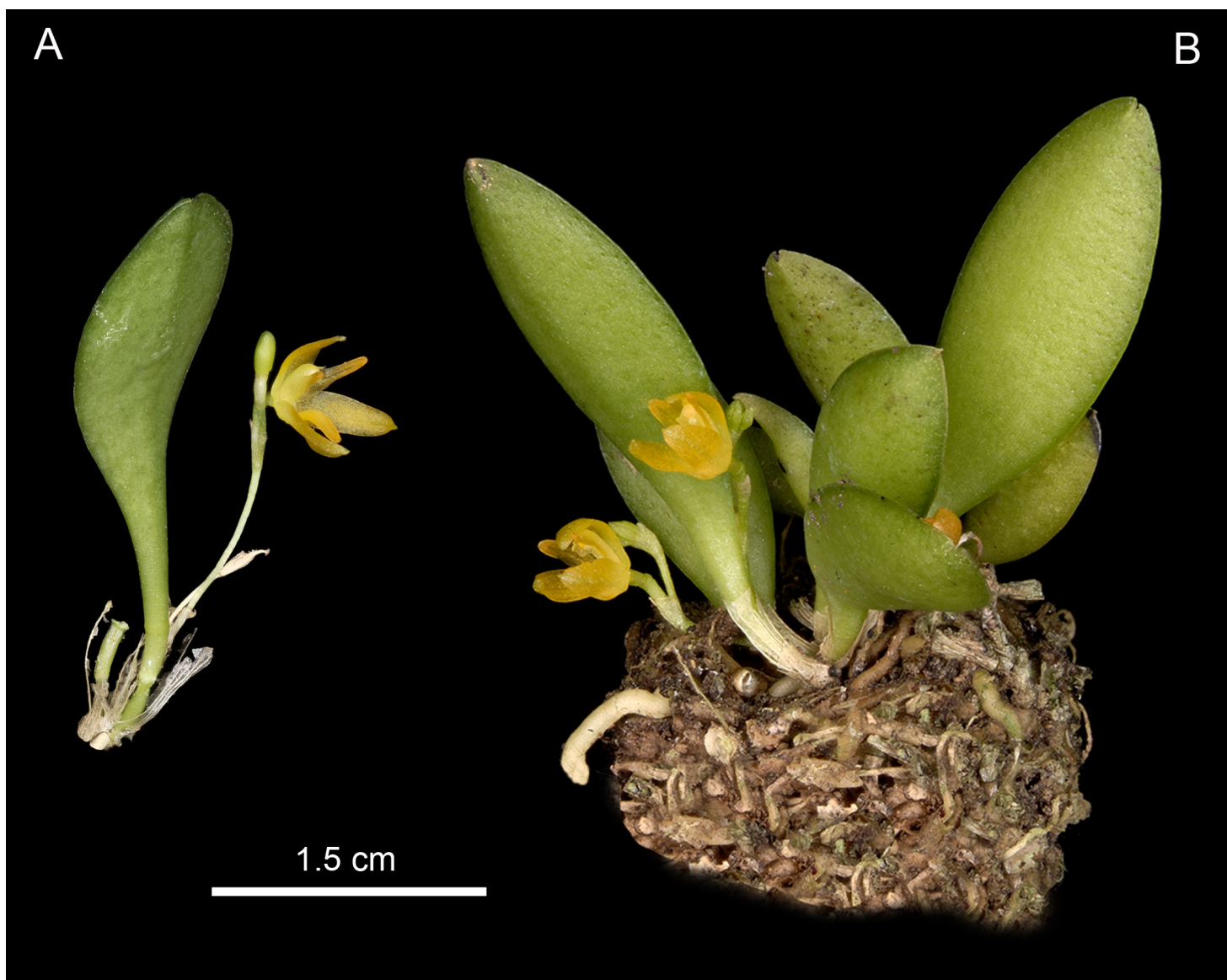

Figure 2. Anathallis luteola. A. Ramicaul, leaf and inflorescence, based on A. Toscano de Brito 3458. B. Habit, based on A. Toscano de Brito 3352. Photographs by W. Collier \& A. Toscano de Brito.

slightly arcuate, the base minutely lobed at the angles, hinged to the column-foot, the disc unnoticeably channeled in the middle, the channel running from the base toward the apex of the lip, the lateral lobes below the middle, minute, glabrous, obtuse, erect, the apex of the lip rounded, the margins entire and shortly recurved; column $1.5-1.8 \mathrm{~mm}$ long, light-yellow with yellow-white anther, semiterete, concave abaxially, the base prolonged into a thick, $5.0-0.7 \mathrm{~mm}$ long columnfoot, broadly winged above the middle, shortly lacerate and dentate at the apex, the anther, rostellum and stigma ventral.

Distribution: So far known to occur in the state of Bahia, northeast Brazil.

Eтyмоlogy: The specific name derives from the Latin adjective luteolus, "pale yellow, yellowish," and refers to the color of the flowers.
Additional specimens examined: Brazil. Bahia: Without precise locality, obtained from a collector, cultivated by Maria Rita Cabral at her property in Paty do Alferes, state of Rio de Janeiro, fl. cult. 14 November 2015, $A$. Toscano de Brito 3458 (UPCB); same collection data, A. Toscano de Brito 3458-A (UPCB). Maracás, Pedra da Fazenda Canabrava, 977 m, 16 June 2018, C. van den Berg \& S. M. Oliveira 2826 (HUEFS [not seen], photographs of the living plant).

Anathallis luteola resembles A. guarujaensis in habit, floral color and shape of floral segments, especially sepals and lip. In A. luteola, flowers are smaller, sometimes about half the size of those in $A$. guarujaensis (in the latter, sepals are $4.5-8.0 \mathrm{~mm} \times$ $1.50-2.25 \mathrm{~mm}$, and petals $3.5-4.0 \mathrm{~mm} \times 1.00-1.25$ $\mathrm{mm})$. The inflorescence produces two flowers that open in succession, sepals are 3-veined, petals are 


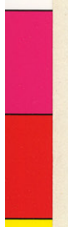

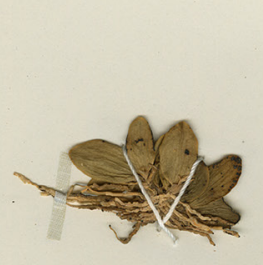
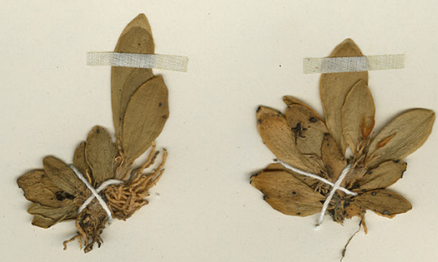

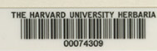
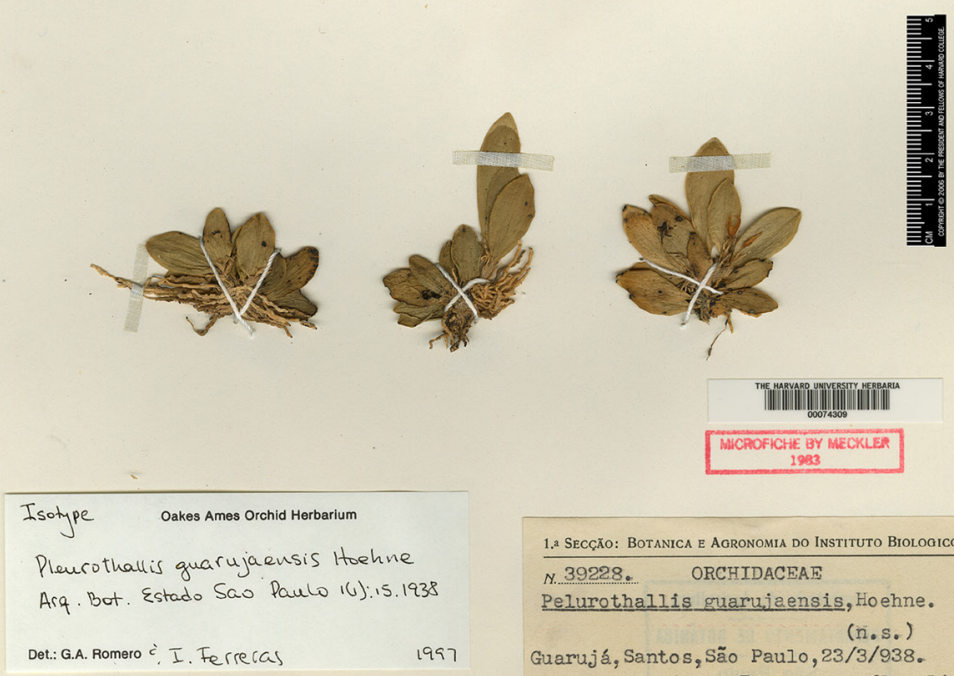

1.a Secç̃o: Botanica e AgRonomia do InstTtuto Broloaico 39228. ORCHIDACEAT Pelurothallis guarujaens is, Hoehne.

(n.s.) Guarujá, Santos, São Paulo, 23/3/938. Mata da Praia das Tartarugas, fl.palido esverdeada.

Leg.Det.F.C.Hoehne.

FiguRE 3. Anathallis guarujaensis. Isotype deposited at AMES. Courtesy of the Orchid Herbarium of Oakes Ames, Harvard University Herbaria. 
obtuse, and the minute, lateral lobules of the lip are glabrous. In A. guarujaensis, inflorescence is singleflowered, sepals are 5 -veined (the laterals sometimes are 4-veined), petals are acuminate, and lateral lobules of the lip are minutely pubescent or densely papillose and more prominent than in A. luteola. At the base of the lip of both species, a pair of minute lobules are found, a lobule on each angle. These are easily overlooked and were omitted in the illustration that appeared in the protologue of A. guarujaensis, whose isotype (F. C. Hoehne s.n., AMES 54792) I examined (Fig. 3). An inaccuracy in the protologue of A. guarujaensis is the number of veins of the sepals, which are illustrated as 3-veined, but they were found to be 5-veined in the isotype at AMES. An additional collection examined of A. guarujaensis (C. Luer 21146, SEL) possesses 5-veined dorsal sepal and 4-veined lateral sepals. Petals are one-veined in both species. Recently, Miranda et al. (2014) published a photograph and a black and white illustration of a specimen of $A$. guarujaensis from the municipality of Caraguatatuba, state of São Paulo, in southeast Brazil. This illustration agrees well with the isotype A. guarujaensis deposited at AMES.

Anathallis luteola was originally collected in the state of Bahia, northeast Brazil, but no precise locality was provided by the collector. More recently, it was collected again in Bahia, this time in the dry Atlantic forests of Maracás, southwest of the state.
Unfortunately, the specimen at HUEFS was not available for study and I only examined photographs of the living material. Despite the lack of precise origin of the specimens studied, this species is distinct and readily recognized from all others in the genus, and for this reason we do not hesitate to describe it as new.

Acknowledgements. The present article is part of the project "The Pleurothallid Orchids of Brazil: Contributions to an inventory and an understanding of evolution, ecology and conservation," currently sponsored by the Marie Selby Botanical Gardens, and "Estudos filogenéticos e taxonômicos em Pleurothallidinae e Oncidiinae - clado Ornithocephalus (Orchidaceae), sponsored by Universidade Federal do Paraná and Coordenação de Aperfeiçoamento de Pessoal de Nível Superior (CAPES), Brazil. I am grateful to CAPES for grant Programa Pesquisador Visitante Especial (PVE), nr. 88881.065009/2014-0; Gustavo A. Romero and Irina Ferrera for their assistance during my visits to the Orchid Herbarium of Oakes Ames (AMES), Harvard University Herbaria, and for providing information on Oakes Ames's collections. I also thank AMES for permission to reproduce the image that appears in Figure 3; Maria Rita Cabral for providing material for study and lodging during my visits; Wade Collier and Nancy Karam, volunteers at SEL, for help in assembling the images and scrutinizing the proofs; Helena Ignowski for preparing the black and white illustrations, and the Marie Selby Botanical Gardens for providing funds for the artwork. I am also grateful to Cássio van der Berg (HUEFS) for sending images of his recent collection from Maracás.

\section{LiTERATURE CITED}

Chiron, G. R., Guiard, J. \& Bolsanello, R. X. (2013). Trois nouvelles espèces de Pleurothallidinae (Orchidaceae) d’Espírito Santo (Brésil). Richardiana, 13, 210-219.

Chiron, G. R., Guiard, J. \& van den Berg, C. (2012). Phylogenetic relationships in Brazilian Pleurothallis sensu lato (Pleurothallidinae, Orchidaceae): evidence from nuclear ITS rDNA sequences. Phytotaxa, 46, 34-58.

Karremans, A. P. (2014). Lankesteriana, a new genus in the Pleurothallidinae (Orchidaceae). Lankesteriana, 13(3), 319-332.

Karremans, A. P. (2015). Visualizing pleurothallids: Lankesteriana. Lindleyana in Orchids (West Palm Beach), 84(5), 304-312.

Karremans, A. P. (2016). Genera Pleurothallidinarum: an updated phylogenetic overview of Pleurothallidinae. Lankesteriana, 16(2), 219-241.

Krahl, A. H., Valsko, J. J., Holanda, A. S. S. \& Chiron, G. R. (2016). Anathallis manausensis (Orchidaceae, Pleurothallidinae), a new species from the Brazilian Amazon. Phytotaxa, 245 (3), 229-233.

Miranda, M. R., Menini Neto, L., Jesus, F. J. \& Chiron, G. R. (2014). Anathallis guarujaensis (Orchidaceae, Pleurothallidinae): redécouverte dúne espèce considérée comme éteinte. Richardiana, 14, 169-175. 
LANKESTERIANA 